\title{
Educating Europe's Managers
}

IT now seems clear that European governments will decide at the end of this week to go ahead with a plan to set up a European Institute of Technology-but without the support of the British Government. The meeting, to be held at OECD headquarters in Paris, is expected to approve the plan for the institute first put forward in a report published in May this year. Despite enthusiasm from a number of European governments, the plan has been cold-shouldered by the British Government. The reason appears to be that the institute differs radically from the one which used to feature regularly in specches by the Prime Minister. What the Prime Minister had in mind, so far as it can be divined, was a kind of European Ministry of Technology, responsible for organizing technological cooperation in Europe. What has emerged is a kind of European graduate school devoted to management education. Promises of support have been fortheoming from the governments of France, West Germany, Italy and Holland, and the institute is almost certain to be sited at Maastricht, in Holland.

The shape and purpose of the institute were first clearly defined in a report issued in May this year, and prepared by a study committee under the chairmanship of M. Giscard d'Estaing. The committec had itself been inspired by a conference on the Technological Gap which was organized at Deauville in May 1967 by the Scientific Committee of the North Atlantic Assembly and the Foreign Policy Research Institute of the University of Pennsylvania. The study committee of fifteen included Dr Alexander King of OECD, the Hon Christopher Layton of PEP, Professor I. I. Rabi of Columbia University and Professor E. Pestel, Rector Designate of Hanover Technical University. Dr D. J. A. Cade, another member, is described in the report simply as a scientific consultant but, in fact, now works at the British Cabinet Office.

The report envisages two kinds of programme which might be undertaken by the institute, which it describes as "an institution of higher education designed to ensure specdier technological progress in Europe". The first is a course intended for graduates in science and engineering, lasting one year, which would provide a training in "the sciences of technological management". The second is a much shorter course, lasting between one and three months, which would be offered to experienced scientists and engineers, and would be focused on "particular topies of research and development management". Four departments are envisaged, covering Advanced Mathematical Methods and Computer Applications, Systems Engineering, Human Sciences and Management of Technology. To start with, about 100 graduate students would be enrolled, but the number could grow to 400 after several years; no country would be allowed to have more than onethird of the graduates. Entry standards would be high-a master's degree or equivalent professional qualification, excellent performance at previous academic studies, and a knowledge of at least two of the operating languages, which will be English, French and German. Diplomas will be awarded to successful students, and ways devised for getting rid of those who are unsuccessful. For staff, the institute would hope to recruit professors from European universities for periods of from two to five years to supplement the small number of permanent staff. Generous salary scales- $\$ 15,000$ to $\$ 18,000$ for full professors, $\$ 8,000$ $\$ 12,000$ for assistant professors - are envisaged. Indeed, the cost of the project, which works out at $\$ 3$ million for 500 full-time students in the fifth year of operation, has been one of the sticking points for the British Government.

So far the two firmest offers of support have come from the Dutch and West German Governments. The Dutch Government has bought the buildings at Maastricht, originally built as a Jesuit Seminary. These are equipped with lecture halls and theatres, a library, administrative offices, a restaurant and 135 bedrooms. The fact that this building could be occupied immediately seems to have swung the balance in its favour, as other attractive sites were offered at Fontaincbleau, Milan and Strasbourg. (The Jesuits, it appears, have decided to concentrate their teaching in a centre of excellence in Amsterdam.) As well as buying the building, the Dutch Government has offered it rent-free for five years-a contribution said to be worth $\$ 2 \cdot 4$ million. 'The Dutch Government has also promised $\$ 100,000$ for the first year of operation, while in the West German budget $\$ 48,000$ has been set aside for the institutc. The French and Italian Governments have expressed support, but nothing is in writing yet.

No decisions have yet been made about the permanent staff for the institute. It will need a DirectorGeneral, a Secretary-General for administration, and a Director of Studics. In the broadest terms, it is thought that the Director-General should be a Europoan - "someone like Lord Jackson", one enthusiast commented. The Director of Studies will probably be American, because this is where the expertise is. The Secretary-Gencral could well be French, to retain balance.

If the decision is made to go ahead, the institute could be admitting its first students at the end of next year. The first advanced course might well be a NATO summer school on the use of advanced mathematical methods in research management, but this has yet to be decided. OFCD, as well as providing a place where governments can meet to discuss the proposals, is also helping by drawing up the legal statutes for the institute. If all goes well, the institute should be under way by September 1969, and one of its supporters says that he expects it to be turning away applicants for lack of places "within eightecn months".

Throughout the discussions, the British Government has taken a cool and detached view of the project. But it has become clear that it has little interest in the idea, which does not fit in with its own plans. Proponents of the institute, however, claim that there is no conflict between the institute and the sort of organization Mr Wilson has talked about. Indeed, they suggest that the two bodies might well be complementary. But the Government, after failing to show any interest when it had the opportunity of influeneing the proposals, now seems to be showing little interast in what has emerged. The investment involved would 
have been $£ 20,000$ in the first year, rising to $£ 200,000$ by the fifth. Of the running cost of the institute, $£ 3$ million in the fifth year, one-third is to come from governments, one-third from private funds (like foundations) and the remaining third from fees from participants and their sponsors.

Despite the British Government's apparent indif- ference to the idea, no special barriers will be put in the way of British students wishing to attend the courses. In principle, at least, the fact that governments have supported the institute does not entitle them to more than their share of the places. Whether this ideal will be realized in practice is, of course, more open to doubt.

\title{
Apollo 8 and the View Beyond
}

\author{
from our Special Correspondent, Washington, December 10
}

T'He Acting Administrator of the National Aeronautics and Space Administration, Dr Thomas Paine, shows every sign of confidence that two Americans will tramp about on the surface of the Moon some time next year. The last flight of a team of three astronauts in October seems enormously to have cheered up those responsible for the Apollo programme. Even the accident this weekend which destroyed one of the machines being used to test the rocket system for descending the last few hundred feet to the surface of the Moon seems to have left them unmoved although, Dr Paine points out, in this business, as in the early days of aviation, an accident "is not serious if the people can walk away from it".

Plans are now well advanced for the journey around the Moon of the Apollo 8 spacecraft, now assembled at Cape Kennedy, due to begin some time during the week of December 21. After that, it may even be possible to decide precisely what test flights will be carried out before a descent to the surface of the Moon is attempted. The situation, in other words, is rather like that at the end of a long car journey when a driver may spend an unpredictable but still comparatively short time hunting about for his destination. There seems no danger that anything will go seriously awry and this suggests instead the analogy with the way in which Moses spent time hunting for the Promised Land.

Dr Paine looks back with mixed feelings over the interval since President Kennedy announced, in 1961, that there would be a serious attempt to send a man to the Moon "before this decade is out". Understandably, he is somewhat downcast that there are critics of the Moon programme even now that success is within sight. In a conversation yesterday he urged that the commitment to such a specific target was probably necessary in order to give the American taxpayer a feeling that his money was being well handled-a sign, said Dr Paine, of "Kennedy's genius for seeing all sides of the problem". In practice, he said, the commitment had turned out to be the only guarantee-people worked on the project as if they were impelled by the urgency of war. But the size of the programme had also made it possible to include within it several items of expenditure that would not otherwise have been possible-the support which the National Aeronautics and Space Administration has given to basic science, for example. If academic scientists were not satisfied with the support they had been given, this may be a sign, said Dr Paine, that they have not been sufficiently persuasive in putting their case. But in any case the outcome of the work now nearing completion in the
Apollo programme was the development of a technological tool which could be used for the rapid advance of science. The orbiting astronomical observatory, launched last week with great success, is one of the examples for which Dr Paine justly claims credit. In general, he said, it was mistaken to believe, as many people did, that if money had not been spent on getting to the Moon, it could promptly be diverted to other things. In any case, he said, the proposal that people should go to the Moon "within this decade" had been coupled with other proposals for development such as a commitment to develop networks of communications and meteorological satellites, for example-and these goals had already been attained.

But what of the future? Dr Paine agreed that the year ahead "is the year that really matters". The budget application which President Johnson will submit to Congress before he leaves office on January 20 and the response to it of the new Administration and of the new Congress will determine whether NASA remains a powerful agency or becomes just a shadow of its former self. Moreover, the decision will have to be made before American taxpayers have had a chance to see whether they have got full value for the $\$ 25$ thousand million which will have been spent on getting to the Moon. What Dr Paine would like to see is a budget of about $\$ 4$ thousand million, much the same as in the present year, and a fairly constant expenditure at that level until the budget would expand again five or six years from now.

Several objectives come quickly to Dr Paine. First, the agency would like to see some use made of the system which has been developed at such cost for launching the Apollo vehicles. What this means is that there should be at least two visits a year to the Moon and at some point, Dr Paine says, it would be necessary to build a shelter there. There is also great interest in schemes for using rocket systems in which the more expensive parts are reusable. The scheme for shuttling rockets in both directions between orbits around the Earth and the Moon is one which offers great advantages. But Dr Paine says that he is also anxious that the programme agreed by Congress for the period after July next year, the beginning of the new fiscal year, should include funds to enable the Administration to develop direct broadcasting communications satellites and surveillance systems for picking out the parts of the surface of the Earth with differing natural resources. Dr Paine also hopes that there will be money for scientific investigations of various kinds: journeys to the planets, of which the scheme to send a 